\title{
Cardiorespiratory Fitness of Inmates of a Maximum Security Prison in Nigeria
}

\author{
Oyeyemi, A.Y., ${ }^{1}$ Jabbo, A.A., ${ }^{2}$ Oyeyemi, A.L., ${ }^{1}$ Aliyu, H.N. ${ }^{1}$ \\ ${ }^{1}$ Department of Physiotherapy, College of Medical Sciences, University of Maiduguri, Maiduguri, Nigeria \\ ${ }^{2}$ Department of Physiotherapy, University of Maiduguri Teaching Hospital, Maiduguri, Nigeria \\ Correspondence \\ Abdul-Hameed A. Jabbo, Department of Physiotherapy, University of Maiduguri Teaching Hospital, \\ Maiduguri, Nigeria・E-mail: aajabbo@gmail.com
}

\begin{abstract}
SUMMARY
Prisoners are a special population group who have limited freedom and are subjected to restrictions. They may not be able to enjoy health enhancing leisure and recreational activities or exercise of their choice or at a time they desire.

The aim of this study is to determine the level of cardiorespiratory fitness (CRF) of inmates in Maiduguri Maximum Security Prison; and also to determine the effects of age, gender, and period of incarceration on CRF.

A total of 247 apparently healthy inmates of Maiduguri Maximum Security Prison participated in the study. The subjects performed a one-mile walk test from which their $\mathrm{VO}_{2} \mathrm{max}$ was derived using a nomogram.

The results show that the prison inmates appear to have a high level of cardiorespiratory fitness. The male inmates were found to have higher cardiorespiratory fitness than their female counterparts, but no significant relationship was found between CRF and period of incarceration, or between CRF and the age of the inmates.

The cardiorespiratory fitness (CRF) of the prison inmates in Maiduguri Maximum Security Prison is good. Further investigation of the influence of other potential variables of physical activity such as vocational facilities and sporting opportunities on the CRF of prison inmates in Maiduguri Maximum Security Prison is necessary.
\end{abstract}

KEY WORDS: prison inmates, incarceration, cardiorespiratory fitness, vocational training

\section{INTRODUCTION}

Prison is a confined environment where persons convicted for crimes serve jail terms and where those undergoing or awaiting trial are remanded. Life in prison is regimented and inmates are subjected to rules and orders limiting their freedom to participate in programmes and activities that they may otherwise engage in if they were not incarcerated. It has been observed that in developing countries and even advanced countries such as Australia, England, and the United States of America, persons incarcerated in maximum security prisons are treated like 'caged animals' (Yogi and Maharishi, 1983). Such men and women may be confined to spaces not bigger than an average bathroom or toilet with little opportunity for physical activity (Ogwezzy, 2011).

Regular physical activity provides benefits for patients with different types of cardiovascular and metabolic diseases as well as apparently healthy individuals. The benefits include increased cardiorespiratory fitness and function, enhanced feeling of well-being, reduced risk of depression, better weight control, and improvement in glucose and blood pressure control and lipid profile (Pate et al., 1995; US Department of Health and Human Services, 2008). Low cardiorespiratory fitness (CRF) has been linked to premature mortality among individuals classified as being normal weight or obese (Wei et al. 1999). With the growing level of awareness on the benefits 
of physical activity, people are motivated to engage in exercises to enhance their health and well-being.

Increasingly, researchers have demonstrated interest in the fitness of children, youth, and adult sub-populations in many countries (Kemper et al., 1989; Batty and Thune, 2000; Willett et al., 2002; Gregg et al., 2003). Similarly, though more recently, interest in the physical fitness of prison inmates, a sub-population often considered to be at risk of physical inactivity and communicable diseases such as tuberculosis, has grown (Pate et al., 1995; US Department of Health and Human Services, 1996 and NIH Consensus Development Panel, 1996).

Prison is deemed a reformation centre and many inmates may become useful members of their communities upon re-entry following the completion of their prison terms. Inmates that are proficient in arts and crafts or who completed apprenticeship training while in prison could become gainfully employed upon re-entry into the society. Skills acquisition in carpentry, tailoring, and welding involve repetitive motion or muscle work that enhances strength, dexterity, and endurance. It is therefore possible that prison inmates who are allowed to engage in sports on available playgrounds, or who are learning different trades, or are involved in other physical activities, may not have their CRF affected during incarceration.

The prisons service in Nigeria is a federal government agency (Nigerian Prison Service [NPS], 2009), and there is a total of 145 convict prisons and 83 satellite prison camps spread across Nigeria. Other prison related institutions are 12 major farm centres, 9 cottage industries, 9 subsidiary farms, 124 market gardens, 3 borstal institutions, 1 open prison camp, 1 staff college, and 4 training schools (NPS, 2009). In Maiduguri Maximum Security Prison, just as in similar prisons spread across Nigeria, it is expected that the inmates would learn a trade. Consequently, facilities for vocational training in carpentry, welding, pottery, tailoring, and other handcrafts exist and inmates may also participate in cooking activities. However, other than a playground that is used as a football field, there are no other recreational facilities in the Maiduguri prison.

Many previous studies have reported on the impact of exercise programmes on the CRF of prison inmates (Pollock and Willmore, 1990; Andrew et al., 2008; Claudia et al., 2013). These studies show that a moderate-intensity exercise programme performed three times a week could lead to improvement in inmates' fitness; and the more the frequency and intensity of training, the better the CRF. The above studies however are on prison inmates in other parts of the world, and only one study (Sulaiman et al., 2010) was found on the CRF of prison inmates in Nigeria.

Inmates of maximum security prisons, who are enrolled in vocational training programmes and where a playground exists and is made available for inmates' use even for a limited time in the day, may have enhanced CRF. Nevertheless, how repetitive work and skills acquisition activities such as carpentry, tailoring, and welding engaged in by inmates affects their CRF, is unclear. Empirical data on prison inmates' CRF elucidates the health status of the inmates and information on the health of inmates is important given the deleterious effect of inactivity to which individuals in confinement may be exposed. This study aims to determine the level of CRF of prison inmates in Maiduguri Maximum Security Prison, and also to explore any influence age, gender, and period of incarceration may have on the CRF of the prison inmates.

\section{METHODS}

\section{Participants}

A total of 247 inmates of Maiduguri Maximum Security Prison participated in this cross-sectional study. The prison has a total capacity of 1600 inmates. The prison cells are divided into three clusters: cluster $1=$ awaiting trial (consists of 10 cells with capacity of 50 inmates each), cluster $2=$ convicts (consists of 12 cells with capacity of 50 inmates each) and cluster $3=$ criminals (consists of 10 cells with capacity of 50 inmates each). However, there were only 648 inmates in the prison, with the number of inmates in each cell less than 23 as at the time of this study in July 2013.

A simple random technique was used to recruit 10 participants each from the 22 cells that housed the male inmates. Because the total number of female inmates was 28 , all of them were selected to participate in the study. Only one female inmate declined to participate in the study. The Yaro Yamane sample size formula was used to determine and confirm that a total sample of 247 inmates is sufficient to power the statistical analysis for this study (Yamane, 1976):

$$
n=N / 1+N(e)^{2}
$$


where:

$N=$ finite population $(648)$

$e=$ limit of tolerable error $(0.05)$

$1=$ constant

\section{Study Procedure}

Ethical approval was sought and obtained from the Ethical Research Committee (ERC) of University of Maiduguri Teaching Hospital (UMTH). A letter containing a detailed description of the nature and purpose of the study and requesting permission, was sent to the Borno State office of the Nigerian Prison Service (NPS) in Maiduguri. On the day of the test, prospective enrollees for the study were brought out and given a detailed verbal description of the nature and purpose of the study. Their informed consent was then sought and obtained.

Consenting participants were made to undergo a onemile walk test, after warm up and stretch exercises of the leg muscles, to determine their level of aerobic fitness. Participants then walked as fast as possible round a 400metre measured track four times for a total of 1 mile. The time taken to walk the mile in minutes and seconds was taken and the 15-seconds immediate post exercise pulse rate was also taken. The one mile walk test is a sub-maximal test that requires subjects to walk one mile as fast as possible without jogging or running (McSwegin et al.; 1998). The Dolgener equation (Dolgener et al., 1994) was used to predict the subjects' $\mathrm{VO}_{2} \mathrm{max}(\mathrm{ml} / \mathrm{kg} / \mathrm{min})$ from the walk time, pulse rate, weight and gender. Participants were then categorized as having high CRF or low CRF using a male and female $\mathrm{VO}_{2} \max$ nomogram as necessary (Heyward, 2006).

\section{Data Analysis}

Descriptive statistics of mean, standard deviation, and proportions $(\%)$ were used to summarize the characteristics and responses of inmates and their CRF. Pearson's correlation test was used to determine the relationship between CRF and period of incarceration and also between $\mathrm{CRF}$ and age of inmates. Independent t-test was used to determine the difference in the CRF and in fitness level by gender.

\section{RESULTS}

A total of 247 apparently healthy inmates participated in the study comprising 220 men $(89.1 \%)$ and 27 women
$(10.9 \%)$. The mean age, body mass index (BMI), and $\mathrm{VO}_{2} \max$ of the participants were $26.34 \pm 6.21$ years, $19.49 \pm 2.68 \mathrm{~kg} / \mathrm{m}^{2}$, and $50.36 \pm 4.73 \mathrm{ml} \mathrm{kg}-1 \mathrm{~min}-1$ respectively. The mean heart rate of participants after the 1-mile walk was 124 beats per minute, while the mean walk time was 13.44 minutes. The mean derived CRF was 50.36 $\mathrm{ml} \mathrm{kg-1} \mathrm{min-1.} \mathrm{This} \mathrm{shows} \mathrm{high} \mathrm{level} \mathrm{of} \mathrm{fitness} \mathrm{among} \mathrm{the}$ inmates. A significantly $(\mathrm{t}=24.17$ and $\mathrm{p}<0.00)$ higher CRF was observed for male inmates $(51.7 \mathrm{ml} \mathrm{kg}-1 \mathrm{~min}-1)$ compared to their female counterparts $(39.1 \mathrm{ml} \mathrm{kg}-1 \mathrm{~min}-$ 1). Data was analysed to explore any relationship between age, period of incarceration, gender, and CRF of participants. No significant relationship was found between CRF and period of incarceration, or between CRF and the age of the inmates.

Table 1. Physical characteristics of participants

\begin{tabular}{llll}
\hline Variables & Mean & SD & Range \\
\hline Age $(\mathrm{yrs})$ & 26.34 & 6.21 & $16-48$ \\
Weight $(\mathrm{kg})$ & 57.10 & 7.30 & $40-95$ \\
Height $(\mathrm{m})$ & 1.71 & 0.09 & $1.00-1.90$ \\
BMI $(\mathrm{kg} / \mathrm{m} 2)$ & 19.50 & 2.68 & $14.20-41.84$ \\
$\begin{array}{l}\text { Period of incarceration } \\
\text { (months) }\end{array}$ & 5.08 & 4.98 & $2-36$ \\
VO ${ }_{2} \mathrm{max}\left(\mathrm{ml} \mathrm{kg}^{-1} \mathrm{mn}^{-1}\right)$ & 50.36 & 4.73 & $32.79-57.2$ \\
\hline
\end{tabular}

Table 2. Differences in performance on 1 mile walk by gender

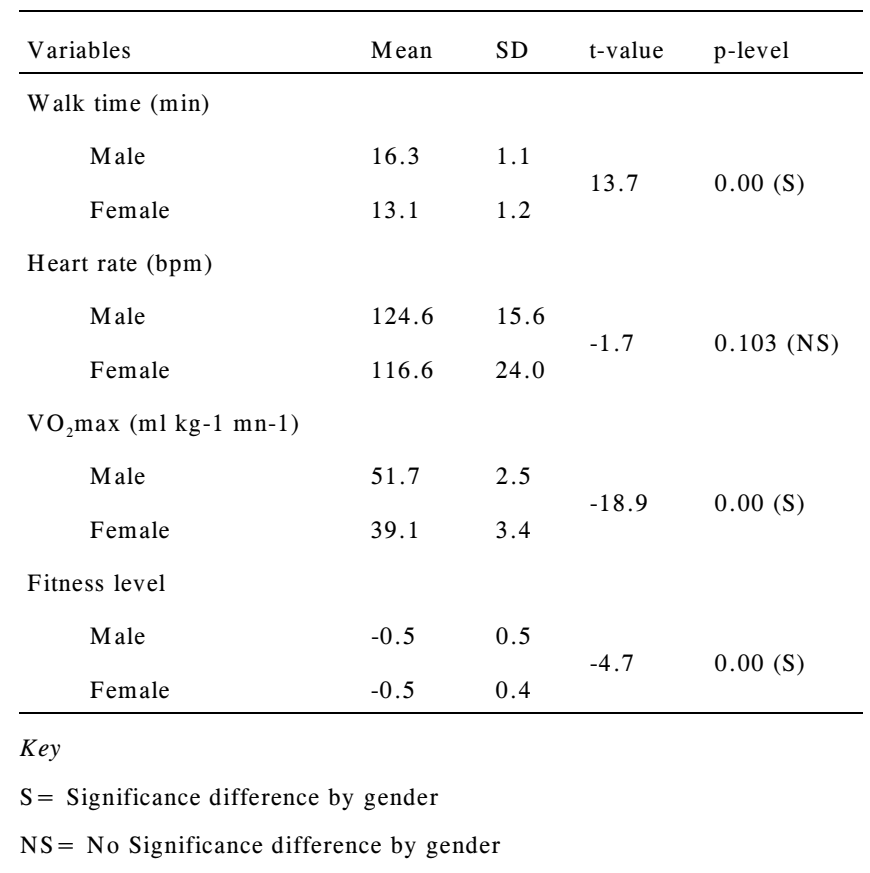




\section{DISCUSSION}

The CRF of the inmates in maximum security prisons as derived from Dolgener's equation seems to be higher than the estimated average $\mathrm{VO}_{2}$ max predicted for the general population (non-inmates). In the general population, the estimated $\mathrm{VO}_{2} \max$ of the average untrained male and female are approximately $45 \mathrm{ml} / \mathrm{kg} / \mathrm{min}$ and $38 \mathrm{ml} / \mathrm{kg} / \mathrm{min}$, respectively (Heyward, 2006).

Going by the standard $\mathrm{VO}_{2}$ max classification for both men and women within the age range of 20-49 (Heyward, 2006), the $\mathrm{VO}_{2} \max$ of these groups of prison inmates could be described as very good or excellent. The significantly higher $(\mathrm{p}<0.05) \mathrm{CRF}$ for male inmates compared to their female counterparts as observed in the present study, affirms differences in the physical characteristics and capacities of both sexes (Heyward, 2006; Thomas and Marianne 2007).

A priori, the fitness level of the inmates in the present study was compared to the fitness level of inmates of a regular non maximum security prison in another city in Northern Nigeria as reported by (Sulaiman et al., 2010). The $\mathrm{VO}_{2}$ max of participants in the present study is double that of participants in the non maximum prison, as reported in the study by Sulaiman et al. The CRF of inmates who had been incarcerated for more than 12 months was compared to those of inmates who had been incarcerated for less than 12 months. In Sulaiman et al.'s study, that of inmates with $\leq 12$ months is slightly higher than that of inmates with $\geq 12$ months of incarceration (26.49 \pm 8.55 vs $20.56 \pm 15.9)$. High CRF levels in the male inmates when compared with their female counterparts are inconsistent with findings in the study by Sulaiman et al. (2010) which shows no difference in CRF by gender.
The reason why the mean $\mathrm{VO}_{2}$ max of inmates in the present study is approximately twice that of inmates in Sulaiman et al.'s study is unclear. No detailed information on how the $\mathrm{VO}_{2}$ max was derived in the study was available. However, the Sulaiman et al. study seems to be the only one available for citation on this topic in Nigeria, and unlike the present study, it suggests that the prevalence of low CRF was high among the prison inmates in Kano. More studies with improved and similar methodology like that of the present study are needed before firm conclusion can be drawn on the direction of the findings for this topic in Nigeria.

Based on the existing knowledge of the relationship between physical activity and CRF, the disparity in the inmates mean CRF between Maiduguri prison inmates and inmates of Kano prison as reported in the study by Sulaiman et al. may be attributed in part to the availability of facilities for vocational training in Maiduguri. Maiduguri prison, like other maximum security prisons in Nigeria, has provisions and facilities for vocational training and sporting activities (NPS, 2009). Although a playground was also available in Kano prison, being a non-maximum security prison, no opportunities were provided for vocational training. This observation is based on information, though anecdotes, from the prison's management. Better opportunities for higher total daily or weekly physical activity which Maiduguri inmates may be able to take advantage of when compared to lower opportunities in Kano prison, may be responsible for the difference in the results of the two studies.

Table 3. Comparison of CRF of inmates in Maiduguri Maximum Security Prison with those of inmates of a Kano prison as reported in a study by Suleiman et al., $2010(\mathrm{~N}=247)$

\begin{tabular}{|c|c|c|c|c|c|c|c|c|}
\hline \multirow[t]{3}{*}{ Variables } & \multicolumn{4}{|c|}{ Suleiman et al., 2010} & \multicolumn{4}{|c|}{ Current Study } \\
\hline & \multicolumn{2}{|c|}{$\begin{array}{c}\leq 12 \text { months } \\
\mathrm{n}=89\end{array}$} & \multicolumn{2}{|c|}{$\begin{array}{c}>12 \text { months } \\
n=27\end{array}$} & \multicolumn{2}{|c|}{$\begin{array}{c}\leq 12 \text { months } \\
n=228\end{array}$} & \multicolumn{2}{|c|}{$\begin{array}{c}>12 \text { months } \\
n=19\end{array}$} \\
\hline & $\mathrm{X}$ & SD & $\mathrm{X}$ & SD & $\mathrm{X}$ & SD & $\mathrm{X}$ & SD \\
\hline Age (yrs) & 28.28 & 7.69 & 29.26 & 8.07 & 26.28 & 6.41 & 27.00 & 3.21 \\
\hline W eight (kg) & 63.42 & 8.90 & 67.59 & 8.32 & 57.04 & 7.30 & 57.73 & 7.53 \\
\hline Height (m) & 1.68 & 0.08 & 1.70 & 0.07 & 1.72 & 0.90 & 1.67 & 0.73 \\
\hline BMI $\left(\mathrm{kg} / \mathrm{m}^{2}\right)$ & 21.96 & 2.83 & 23.24 & 2.56 & 19.37 & 2.23 & 20.10 & 5.27 \\
\hline Period of incarceration (months) & 4.12 & 3.56 & 28.41 & 14.14 & 4.00 & 2.32 & 18.10 & 8.85 \\
\hline $\mathrm{VO}_{2} \max (\mathrm{ml} / \mathrm{kg} / \mathrm{min})$ & 26.49 & 8.55 & 20.56 & 15.97 & 50.38 & 4.80 & 50.04 & 3.92 \\
\hline
\end{tabular}




\section{Study Limitations}

Findings on the CRF of inmates from a single centre such as in the present study should be generalized with caution. This is partly because Maiduguri prison inmate population may not be representative of the maximum prison population in Nigeria. Perhaps the high CRF among inmates in the present study is a transient phenomenon. As the prison becomes filled with inmates, it is plausible that the competition for space and use of equipment and vocational facilities may cause changes in the inmates' exercise and physical activity behaviour that could reduce their CRF.

Overcrowding in prisons is a serious problem both in Nigeria and the world over (Amnesty International, 2008). In many prisons in Nigeria, inmates sleep two to a bed or on the floor in filthy cells due to congestion or overcrowding (Ogwezzy, 2011). At present, the capacity of Maiduguri Maximum Security Prison is 1600 , but there were only 648 inmates incarcerated as at July 2013, during the period of the study. Therefore, unlike most prisons in Nigeria, Maiduguri Maximum Security Prison is not overcrowded.

Furthermore, Dolgener's equation has been validated for a general population other than in Nigeria and the equation has been reported to be less accurate in predicting the $\mathrm{VO}_{2} \mathrm{max}$ that falls at a higher range compared to those at an average or lower range. Further study is needed to compare the aerobic fitness of inmates in a maximum security prison where sporting activities and vocational training exist, with a contiguous non maximum security prison where no similar opportunities exist using a uniform standardized test of aerobic fitness.

\section{CONCLUSION}

This study shows that the CRF of the prison inmates in Maiduguri Maximum Security Prison was good, and that the male prisoners have a higher CRF than the female prisoners. The CRF of this group of prisoners is higher than that in the general population, but further studies are needed to determine the influence of other variables such as vocational facilities and sporting opportunities on the CRF of prison inmates in Maiduguri, Nigeria.

\section{REFERENCES}

Amnesty International. 2008. Nigeria: Prisoners Rights Systematically Flouted. AI Index: AFR 44/001/2008. Amnesty International Publications.
Andrew C., Emily P., Warren S., Kerri D. and Diane M. 2008. Fit for prison: Special population health and fitness programme evaluation. International Journal of Prisoner Health 4(4): 208216.

Batty D. and Thune I. 2000. Does physical activity prevent cancer? Evidence suggests protection against colon cancer and probably breast cancer. British Medical Journal 2000; 321: 1424-1425.

Beck A.J. and Mumola C. J. 1998. Prisoners, Bureau of Justice Statistics Bulletin. August 1999, NCJ 175687. Office of Justice Programs. U.S. Department of Justice Online at http://www.ojp.usdoj.gov/bjs. Accessed May 23rd 2012.

Claudia B., Alessandra D., Giovanni F., Arrigo G., Federica F., Paolo, B., Marco, M. and P. Fabio. 2013. International Journal of Environmental Research and Public Health 10: 5683-5696; doi: 103390/ ijerph10115683.

Dolgener F.A., Hensley L.D., Harsh J.J. and Fjelstul J.K. 1994. Validation of the rockport fitness walking test in college males and females. Research Quarterly for Exercise and Sport 65: 152-158.

Gregg E.W., Cauley J.A., Stone K., Thompson T.J., Bauer D.C., Cummings S.R. and Ensrud K.E. 2003. Relationship of change in physical activity and mortality among older women. Journal of American Medical Association 289: 2379-2386.

Heyward V.H. 2006. Advanced Fitness Assessment and Exercise Prescription, 5th edition, Champaign IL: Human Kinetics.

Kemper G.H., Verschuur R. and Demey L. 1989. Longitudinal change of aerobic fitness in youth aged 12-23. Paediatric Exercise Science 1: 257-270.

McSwegin P.J., Plowman S.A., Wolff G.M. and Guttenberg G.L. 1998. Measurement of Physical Performance. Philadelphia P.A: Lea and Febiger.

Michael C.O. 2011. From reformation to deformation: An approach towards sustainable development of the defective prison system in Nigeria. Journal of Sustainable Development in Africa 13(7).

National Institute of Health and U.S Department of Health and Human Services. 1996. Consensus Development Panel On Physical Activity and Cardiovascular Health. Journal of American Medical Association 276: 241-246.

Nigerian Prison Service. 2009. http://preminternational.org/prinigeria.html Accessed on 20th November 2010.

Ogwezzy M.C. 2011. From reformation to deformation: An approach towards sustainable development of the defective prison system in Nigeria. Journal of Sustainable Development in Africa, www.jsda.africa.com/jsda/vol13no7-winter2011 Accessed March 20th, 2015.

Pate R.R., Prat M., Blair S.N., Haskell, W.L., Macera C.A., Bourchard C., et al. 1995. Physical activity and public health: A recommendation from the Centers for Disease Control and Prevention. American College of Sports Medicine 273: 402407. 
Pollock M.L. and Willmore J. 1990. Exercise in Health and Disease: Evaluation and prescription for prevention and rehabilitation ( $2^{\text {nd }}$ ed.) Philadelphia: Saunders.

Sulaiman A.O., Hanif S., Lamina S. and Isa U.L. 2010. Correlates of selected indices of physical fitness and duration of incarceration among inmates in some selected Nigerian prisons. Ethopian Journal of Health Sciences 20(1): 65-69. Accessed online May 11 ${ }^{\text {th }}, 2011$.

Thomas E.H. and Marianne S.G. 2007. Conservative Management of Sports Injuries 2nd ed. Sudbury, Mass.: Jones and Bartlett, 2007. Accessed May, $23^{\text {rd }} 2011$.

US Department of Health and Human Services. 2008. The Physical Activity Guideline Advisory Committee Report 2008. Washington DC: US.

Available at http://www.health.gov/paguidelines/. Accessed December. 12, 2015.
Wei M., Kampert J.B., Barlow C.E., Nichaman M.Z., Gibbons L.W., Paffenbarger Jr. R.S. and Blair S.N. 1999. Relationship between low cardiorespiratory fitness mortality in normal weight and obese men. Journal of American Medical Association 282: 1547-1553.

Willett W., Feskanich D. and Colditz G. 2002. Walking and leisure-time activity and risk of living in postmenopausal women. Journal of American Medical Association 2002; 288: 2300-2306.

Yamane Y. 1976. Simplified Method to Calculate Sample Size. Edis. Ifas. UFL.edu/pd 006. Accessed November 2010.

Yogi M. and Maharishi K. 1983. Yoga for Correction and Criminal Justice. Vol. 29. Lucknow: Madhur Publication. pp.1-35. 